\section{Soil Gas, Temperature, Matric Potential, and Creeping Bentgrass Growth Response to Subsurface Air Movement on a Sand-based Golf Green}

\author{
B. Todd Bunnell ${ }^{1}$ \\ Department of Horticulture, Clemson University, Clemson, SC 29634-0375 \\ Lambert B. McCarty ${ }^{2}$ \\ Department of Horticulture, Clemson University, Clemson, SC 29634-0375
}

Hoke S. Hill ${ }^{3}$

Department of Experimental Statistics, Clemson University, Clemson, SC 29634-0375

Additional index words. creeping bentgrass, Agrostis palustris, oxygen diffusion rate (ODR), golf greens, soil gases, root growth, turf quality, carbon dioxide $\left(\mathrm{CO}_{2}\right)$, oxygen $\left(\mathrm{O}_{2}\right)$

Abstract. Creeping bentgrass (Agrostis palustris Huds.) is used on putting greens for its fine-leaf texture, consistent speed, smooth ball roll, and year-round color. In recent years bentgrass use has extended into the warmer climates of the southern United States. Being a $\mathrm{C}_{3}$ plant, bentgrass is not well adapted to extended hot and humid environmental conditions. Subsurface air movement systems are now commercially available that can transport air through the root zone to alter soil conditions and potentially improve bentgrass survival. This research investigated the effects of subsurface air movement on the composition of soil gases, matric potential, temperature, and growth response of a sand-based creeping bentgrass golf green. Treatments included: air movement direction (evacuate, inject, and no air) and duration of air movement (0400-0600 HR, 1000-1800 HR, and 24 hours). Treatment combinations were imposed for 13 days. Subsurface air movement reduced $\mathrm{CO}_{2}$ at the $9-\mathrm{cm}$ depth to values $<0.0033 \mathrm{~mol} \cdot \mathrm{mol}^{-1}$ when evacuating or injecting air, depending upon duration. Soil matric potentials at a 9-cm depth were decreased by a maximum of $96 \%$ when evacuating air for 24 -hour duration compared to no-air plots. Soil temperatures at $9 \mathrm{~cm}$ were decreased $\approx 1$ to $1.5^{\circ} \mathrm{C}$ when injecting air from 1000 to $1800 \mathrm{HR}$ and 24 -hour treatments and increased $\approx 0.75^{\circ} \mathrm{C}$ when evacuating air from 1000 to $1800 \mathrm{HR}$. Subsurface air movement did not improve creeping bentgrass turf quality or rooting. Although not effective in improving the growth response of creeping bentgrass, subsurface air movement may be a useful tool to improve soil gas composition, reduce excess soil moisture, and potentially reduce soil temperature(s) of heat-stressed creeping bentgrass golf greens.

Maintaining creeping bentgrass to high quality golf green standards includes low mowing heights $(3 \mathrm{~mm})$, intense foot and machine traffic, and frequent watering. Creeping bentgrass is natively adapted to air temperatures of 15 to $24^{\circ} \mathrm{C}$ and soil temperatures of 10 to $18{ }^{\circ} \mathrm{C}$ (Beard, 1973; McCarty, 2001). During summer months, maximum air and soil temperatures often exceed $30^{\circ} \mathrm{C}$ in the southern transition zone, making creeping bentgrass difficult to grow. Proper greens construction guidelines have been developed to enhance creeping bentgrass summer survival and improve soil characteristics. One of the first involved a uniform root zone modification in

Received for publication 30 Dec. 2002. Accepted for publication 22 May 2003. Technical Contribution No. 4981 of the Clemson Univ. Experiment Station. Research conducted at Clemson Univ., Clemson, S.C. Use of trade names does not imply endorsement of the products named nor criticism of similar ones not named.

'Research Manager; e-mail: toddb@sepro.com

2Professor; e-mail: bmccrty@clemson.edu

${ }^{3}$ Professor; e-mail: hhill@clemson.edu the late 1950s, when the U.S. Golf Association (USGA) adopted specifications for golf greens construction to improve drainage and soil aeration (USGA Greens Section Staff, 1960). Current USGA guidelines recommend $30 \mathrm{~cm}$ of a sand-organic matter mix atop a $10-\mathrm{cm}$ bed of 2- to $12-\mathrm{mm}$-diameter gravel, covering drain lines trenched into the sub-grade (USGA Green Section Staff, 1993). The high sand content provides a porous medium that maintains positive soil aeration and rapidly drains excess water.

A recent innovation is the capability of injecting or evacuating ambient air through the porous soil column of sand-based rootzone golf greens via subsurface drain lines in attempts to improve the soil atmosphere during summer months by purging of unwanted gases, removal of excess water, and potential root-zone cooling. Commercial air-exchange units utilize a blower/vacuum apparatus attached to the main drain line outlet of a golf green. The proposed advantages are improved soil aeration, purging of unwanted gases, rootzone cooling, improved soil water status, and overall improved root and shoot performance (Dodd et al., 1999). A 3-year study in Conway, S.C., found improved turf quality, shoot density, and rooting following continuous subsurface air injection during summer months (Camberato, 2000). A similar study in Alabama demonstrated an $\approx 25 \%$ increase in root length and weight in response to subsurface aeration treatments (Walker, 2000).

Limited research has been conducted on subsurface air injection/evacuation and soil responses. Preliminary results showed temperatures in the root zone to be increased or decreased as much as $2{ }^{\circ} \mathrm{C}$ during summer months, depending upon direction of air movement (Camberato et al., 2000; Dodd etal., 1999). When air evacuation treatments were applied in the afternoon, soil temperatures increased $2{ }^{\circ} \mathrm{C}$ at the $10-\mathrm{cm}$ depth; whereas temperatures decreased $2^{\circ} \mathrm{C}$ at the same depth when air was injected. Soil temperatures at 10 $\mathrm{cm}$ were decreased by $2{ }^{\circ} \mathrm{C}$ at night regardless of direction of air movement. A recent study demonstrated that subsurface air injection decreased soil temperatures by a maximum of $2{ }^{\circ} \mathrm{C}$ (Walker et al., 2000). Additionally, air evacuation treatments have been found to significantly decrease soil volumetric water contents, especially at the lower depths of the root zone (Bigelow et al., 2001)

In addition to temperature and soil moisture effects, other potential advantages to subsurface air movement include soil oxygenation and purging of unwanted gases, such as carbon dioxide $\left(\mathrm{CO}_{2}\right)$, methane $\left(\mathrm{CH}_{4}\right)$, and hydrogen sulfide $\left(\mathrm{H}_{2} \mathrm{~S}\right)$. During summer months, plant soil $\mathrm{O}_{2}$ needs are greatest due to high temperatures that stimulate plant root and microbial respiration (Waddington and Baker, 1964; Williamson, 1964). Huang et al. (1998) reported reduced bentgrass quality as temperatures increased and soil aeration decreased. High 35 ${ }^{\circ} \mathrm{C}$ day $/ 25^{\circ} \mathrm{C}$ night temperatures and limiting soilO $_{2}\left(2.0 \times 10^{-7} \mathrm{~g} \cdot \mathrm{cm}^{-2} \cdot \mathrm{min}^{-1}\right)$ reduced overall root viability and root dry matter. Dodd et al. (1999) reported soil $\mathrm{O}_{2}$ increased and $\mathrm{CO}_{2}$ decreased using subsurface air movement in both directions. Therefore, our study objective was to determine the effects of differing directions and durations of subsurface air movement on soil matric potential, soil atmosphere gas concentrations $\left(\mathrm{O}_{2}\right.$ and $\left.\mathrm{CO}_{2}\right)$, soil temperature, and creeping bentgrass growth response in a sand-based golf green.

\section{Materials and Methods}

The study was conducted in 1999 on a creeping bentgrass research green at Clemson, S.C. The green was seeded in Sept. 1997 with $59 \mathrm{~kg} \cdot \mathrm{ha}^{-1}$ 'Crenshaw' creeping bentgrass. Soil profile construction and soil physical properties followed USGA recommendations with a 85 sand: 15 peat (v:v) mix (USGA, 1993) (Tables 1 and 2). The grass was maintained to golf course standards, including daily mowing at 4 mm and irrigation applied from 0600 to $0700 \mathrm{HR}$ twice weekly at $1.9 \mathrm{~cm}$ per application. During spring and summer months, fungicides were applied every $14 \mathrm{~d}$ for disease control. Within the green were three $190-\mathrm{m}^{2}$ cells $(13.8 \mathrm{~m} \times$ 
Turf Management

$13.8 \mathrm{~m}$ ) separated by vertical polyvinyl chloride (PVC) sheeting, which allowed for individual cell drainage. Within each cell, three connecting drainlines (10-cm diameter) spaced $4.6 \mathrm{~m}$ apart delivered desired direction and duration of subsurface air movement. Within individual cells, three $4.5 \mathrm{~m} \times 7 \mathrm{~m}$ subsample plots were established, each containing a single drainline. Each subsample plot contained a valve box housing tensiometers and thermocouples at 9- and 20-cm depths.

Subsurface air movement was applied via two specially designed $5.6-\mathrm{kW}$ air pumps (model no. ES1867; SubAir, Deep River, Conn.), each equipped with a butterfly valve for air direction control as either injection (positive) or evacuation (negative). Each pump delivered $4 \mathrm{~cm}$ of water pressure within each individual cell at the soil surface. Pumps were connected to a 20 -cm-diameter drain line leading into air-water separator vaults. The vault was connected to a 15 -cm-diameter drain running the perimeter of the research plot. Individual cells were fitted with a gate valve to regulate subsurface air movement. Drain size was reduced to the standard $10-\mathrm{cm}$-diameter perforated pipe beneath the green.

The study was a randomized completeblock design (RCBD) with a split-plot treatment arrangement. Direction of subsurface air-flow was the whole plot treatment and duration of air flow was the split unit treatment. Three subsamples were taken for each treatment combination within each block. Two complete runs of the experiment represented the two blocks of the study.

Daily duration treatments were applied to separate cells from 0400 to $0600 \mathrm{HR}, 1000$ to $1800 \mathrm{HR}$, or $24 \mathrm{~h}$. Within duration treatments, three levels of air movement direction were evaluated: injection, evacuation, or no air (control). Control plots, without subsurface air movement, were also included for each treatment group. All three duration sequences were performed to represent a run. The first run occurred 1 June to 19 July 1999 , with 0400 to $0600 \mathrm{HR}$ treatment performed 1 to 13 June, 1000 to $1800 \mathrm{HR}$ performed 19 June to 1 July, and $24 \mathrm{~h}$ performed 7 to $19 \mathrm{July}$. After the first run, plots were randomly reassigned to different cells. The second run occurred 24 July to 10 Sept. 1999, with 0400 to 0600 HR performed 24 July to 6 Aug., 1000 to 1800 HR performed 11 to $23 \mathrm{Aug}$., and $24 \mathrm{~h}$ performed $29 \mathrm{Aug}$. to 10 Sept. Duration factor levels were implemented for 13-d periods with a 5-d interval between durations to allow cells to equilibrate from the preceding treatment.

The obvious expense and logistical difficulties of building this research setting precluded having two physically different blocks for simultaneous study. Therefore, the second experimental run was in the same study area. However, this second run is a true replicate since whole and split plot treatments were randomly reassigned and run at a completely different time. Therefore, treatment combinations were replicated in both time and space.

Soil matric potential was measured with tensiometers (model TGA; Irrometer, Riverside, Calif.) housed in valve boxes, placed

Table 1. Particle size distribution percentages of sand used in the research green at Clemson Univ. compared with USGA recommendations for golf greens.

\begin{tabular}{|c|c|c|c|c|c|c|c|c|c|}
\hline \multirow[b]{3}{*}{ Sample } & & & & \multicolumn{6}{|c|}{$\begin{array}{c}\text { Sieve size/sand fraction } \\
\text { Sand particle diam \% retained }\end{array}$} \\
\hline & \multicolumn{3}{|c|}{ Soil separation $(\%)$} & \multirow{2}{*}{$\begin{array}{l}\text { Gravel } \\
(2 \mathrm{~mm})\end{array}$} & \multirow{2}{*}{$\begin{array}{l}\text { Very coarse } \\
(1 \mathrm{~mm})\end{array}$} & \multirow{2}{*}{$\begin{array}{l}\text { Coarse } \\
(0.5 \mathrm{~mm})\end{array}$} & \multirow{2}{*}{$\begin{array}{l}\text { Medium } \\
(0.25 \mathrm{~mm})\end{array}$} & \multirow{2}{*}{$\begin{array}{c}\text { Fine } \\
(0.15 \mathrm{~mm})\end{array}$} & \multirow{2}{*}{$\begin{array}{l}\text { Very fine } \\
(0.05 \mathrm{~mm})\end{array}$} \\
\hline & $\overline{\text { Sand }}$ & Silt & Clay & & & & & & \\
\hline $\begin{array}{l}\text { Clemson } \\
\text { mix }\end{array}$ & 98.0 & 1.0 & 1.0 & 0.1 & 3.2 & 27.9 & 51.7 & 12.0 & 3.1 \\
\hline $\begin{array}{l}\text { USGA } \\
\text { value }\end{array}$ & $\geq 92 \%$ & $\leq 3 \%$ & $\leq 3 \%$ & $\begin{array}{l}\leq 3 \% \mathrm{C} \\
\leq 10 \% \mathrm{C}\end{array}$ & $\begin{array}{l}\text { Gravel } \\
\text { Combined }\end{array}$ & $\geq 60$ & $0 \%$ & $20 \%$ & $\leq 5 \%$ \\
\hline
\end{tabular}

Table 2. Soil physical properties of sand used in research green at Clemson Univ. compared with USGA recommendations for golf greens.

\begin{tabular}{lccccccc}
\hline & $\begin{array}{c}\text { Particle } \\
\text { density } \\
\left(\mathrm{g} \cdot \mathrm{cm}^{-3}\right)\end{array}$ & $\begin{array}{c}\text { Bulk } \\
\text { density } \\
\left.\mathrm{g} \cdot \mathrm{cm}^{-3}\right)\end{array}$ & $\begin{array}{c}\text { Infiltration } \\
\text { rate } \\
\left(\mathrm{cm} \cdot \mathrm{h}^{-1}\right)\end{array}$ & $\begin{array}{c}\text { Total } \\
\text { porosity } \\
(\%)\end{array}$ & $\begin{array}{c}\text { Aeration } \\
\text { porosity } \\
(\%)\end{array}$ & $\begin{array}{c}\text { Capillary } \\
\text { porosity } \\
(\%)\end{array}$ & $\begin{array}{c}\text { Organic } \\
\text { matter } \\
(\%)\end{array}$ \\
Sample & 2.64 & 1.41 & 17 & 46.8 & 23.4 & 23.3 & 1.4 \\
Clemson mix & & $1.3-1.6$ & $15-60$ & $33-58$ & $15-30$ & $15-25$ & $0.7-3.0$ \\
USGA value & & &
\end{tabular}

Table 3. Soil $\mathrm{O}_{2}, \mathrm{CO}_{2}$, and matric potential (1000 and $1500 \mathrm{HR}$ ) at 9- and 20-cm depth below the soil surface as affected by injecting or evacuating subsurface air through the soil profile either 0400 to $0600 \mathrm{HR}$, 1000 to $1800 \mathrm{HR}$, or 24-h intervals.

\begin{tabular}{|c|c|c|c|c|c|c|c|}
\hline \multirow[b]{2}{*}{$\begin{array}{l}\text { Treatment } \\
\text { duration }\end{array}$} & \multirow[b]{2}{*}{$\begin{array}{c}\text { Air } \\
\text { movement } \\
\text { treatment }\end{array}$} & \multicolumn{3}{|c|}{ Soil depth $=9 \mathrm{~cm}$} & \multicolumn{3}{|c|}{ Soil depth $=20 \mathrm{~cm}$} \\
\hline & & $\begin{array}{c}\mathrm{O}_{2} \\
\left(\mathrm{~mol} \cdot \mathrm{mol}^{-1}\right)\end{array}$ & $\begin{array}{c}\mathrm{CO}_{2} \\
\left(\mathrm{~mol} \cdot \mathrm{mol}^{-1}\right)\end{array}$ & $\begin{array}{c}\text { Matric } \\
\text { potential } \\
(\mathrm{kPa})\end{array}$ & $\begin{array}{c}\mathrm{O}_{2} \\
\left(\mathrm{~mol} \cdot \mathrm{mol}^{-1}\right)\end{array}$ & $\begin{array}{c}\mathrm{CO}_{2} \\
\left(\mathrm{~mol} \cdot \mathrm{mol}^{-1}\right)\end{array}$ & $\begin{array}{c}\text { Matric } \\
\text { potential } \\
(\mathrm{kPa})\end{array}$ \\
\hline \multirow[t]{3}{*}{$0400-0600$} & No air & $0.204 \mathrm{a}^{\mathrm{z}}$ & $0.0067 \mathrm{a}$ & $-4.82 c$ & $0.204 \mathrm{a}$ & $0.0045 \mathrm{a}$ & $-2.98 c$ \\
\hline & Evacuate & $0.205 \mathrm{a}$ & $0.0033 \mathrm{~b}$ & $-6.02 \mathrm{a}$ & $0.205 \mathrm{a}$ & $0.0027 \mathrm{a}$ & $-4.07 \mathrm{a}$ \\
\hline & Inject & $0.205 \mathrm{a}$ & $0.0033 \mathrm{~b}$ & $-5.35 \mathrm{~b}$ & $0.205 \mathrm{a}$ & $0.0018 \mathrm{a}$ & $-3.75 b$ \\
\hline \multirow[t]{3}{*}{$1000-1800$} & No Air & $0.204 \mathrm{a}$ & $0.0029 \mathrm{a}$ & $-3.84 c$ & $0.203 \mathrm{a}$ & $0.0068 \mathrm{a}$ & $-2.57 \mathrm{c}$ \\
\hline & Evacuate & $0.205 \mathrm{a}$ & $0.0012 \mathrm{~b}$ & $-5.44 \mathrm{a}$ & $0.204 \mathrm{a}$ & $0.0020 \mathrm{~b}$ & $-3.92 \mathrm{a}$ \\
\hline & Inject & $0.205 \mathrm{a}$ & $0.0011 \mathrm{~b}$ & $-4.40 \mathrm{~b}$ & $0.204 \mathrm{a}$ & $0.0016 \mathrm{~b}$ & $-3.32 \mathrm{~b}$ \\
\hline \multirow[t]{3}{*}{$24 \mathrm{~h}$} & No Air & $0.206 \mathrm{a}$ & $0.0025 \mathrm{a}$ & $-2.91 \mathrm{c}$ & $0.205 \mathrm{a}$ & $0.0038 \mathrm{a}$ & $-2.00 \mathrm{c}$ \\
\hline & Evacuate & $0.208 \mathrm{a}$ & $0.0004 \mathrm{~b}$ & $-4.86 \mathrm{a}$ & $0.208 \mathrm{a}$ & $0.0004 \mathrm{a}$ & $-3.93 \mathrm{a}$ \\
\hline & Inject & $0.208 \mathrm{a}$ & $0.0005 \mathrm{~b}$ & $-3.61 b$ & $0.208 \mathrm{a}$ & $0.0004 \mathrm{a}$ & $-2.80 \mathrm{~b}$ \\
\hline
\end{tabular}

${ }^{\mathrm{z}}$ Means followed by the same letter are not significantly different within each duration treatment and variables according to Fisher's LSD $\left(P=0.05\right.$ for $\mathrm{O}_{2}$ and $\mathrm{CO}_{2}$ and $P=0.10$ for soil matric potential $)$ test.

horizontally in the soil at 9- and 20-cm depths. Valve boxes, containing a tensiometer at each depth, were placed in each subsample plot. Tensiometers were filled with water and primed with a vacuum pump weekly. Tensiometer readings $(\mathrm{kPa})$ were recorded twice daily at 1000 and $1500 \mathrm{HR}$. Sampling time was nonsignificant for soil matric potential; therefore, readings were averaged and pooled.

Soil temperature readings were taken in each subsample plot at 9- and 20-cm depths using thermocouples constructed by the attachment of a copper wire with a copper-nickel wire. The two wires were soldered together and covered with a $0.6-\mathrm{cm}$-diameter stainless steel pipe (encased in epoxy) for protection and thermal distribution. Thermocouple wire was buried in the soil profile at the desired depth. Due to data similarities between the two depths, only the 9-cm data are reported. Ambient air temperatures and soil temperatures were recorded every $60 \mathrm{~s}$ and averaged every hour with a datalogger (model CR-10X; Campbell Scientific, Logan, Utah). Hourly soil and ambient air temperatures were averaged over each 13-d duration/direction run. Standard errors were calculated for hourly soil temperature data. Data between runs were not pooled due to fluctuating ambient temperatures.

The composition of the soil atmosphere, $\mathrm{O}_{2}$ and $\mathrm{CO}_{2}$, was measured with a portable infrared gas analyzer (model no. 1810-2772; Soil Scientific, Deep River, Conn.). Daily gas readings $\left(\mathrm{mol} \cdot \mathrm{mol}^{-1}\right)$ were at 1000 and 1500 HR. Two measurements at each depth were taken and averaged from each subsample plot using a soil gas port with fixed depths of 9 and $20 \mathrm{~cm}$. The soil gas port consisted of two separate stainless steel pipes $(0.5-\mathrm{cm}$ diameter) with a gas entry slit at the $9-$ and $20-\mathrm{cm}$ depth. Sampling time was nonsignificant for gas concentration; therefore, readings were averaged and pooled.

Root measurements were taken with a 5-cm-diameter $\times 30$-cm-deep soil core at the completion of each 13-d treatment. Two root samples were taken per subsample. Root depth measurements involved averaging of the two deepest roots $(\mathrm{cm})$. Root mass was measured by washing sand and organic matter with an automated, pressurized root washer (Smucker et al., 1982). Samples were dried at $80^{\circ} \mathrm{C}$ for 3 $\mathrm{d}$, then weighed $(\mathrm{g})$ and averaged over the two reps. Root depth and mass were nonsignificant among treatment combinations; therefore, the data will not be shown.

Visual ratings of turf quality, comprising color, health, density, and uniformity, were observed daily. No visual differences were detected at any point in the study; therefore, ratings will not be shown.

Statistical analysis. Data were analyzed using analysis of variance (ANOVA) general 
linear model procedure (GLM) (SAS Institute, 1987). Mean separation was performed using least significant differences with $\alpha=0.05$. Due to inherent variability of soil measurements, an $\alpha=0.10$ was used for the soil matric potential and root data (Wiecko, 1993). Mean separations were only performed between air direction treatments within duration time. Treatments with differing duration were not compared against one another because soil and environmental factors were not consistent over time. ANOVA and mean separations were not performed on soil temperature data. Rather, average temperature results are shown graphically over a $24-\mathrm{h}$ period to indicate cooling and/or heating effects in relation to ambient air temperature.

\section{Results and Discussion}

Soil gases. Subsurface air movement from 0400 to $0600 \mathrm{HR}$ did not alter soil $\mathrm{O}_{2}$ concentrations at either depth (Table 3). Carbon dioxide levels measured at $9 \mathrm{~cm}$ decreased $\approx 50 \%$, from 0.0067 to $0.0033 \mathrm{~mol} \cdot \mathrm{mol}^{-1}$ when evacuating and injecting air. At the $20-\mathrm{cm}$ depth, air movement in either direction had no effect on soil $\mathrm{CO}_{2}$.

Subsurface air movement between 1000 and $1800 \mathrm{HR}$ also did not affect soil $\mathrm{O}_{2}$ at either depth (Table 3). At $9 \mathrm{~cm}, \mathrm{CO}_{2}$ decreased $\approx 59 \%$ and $62 \%$, from 0.0029 to 0.0012 and $0.0011 \mathrm{~mol} \cdot \mathrm{mol}^{-1}$ following evacuating and injecting air, respectively. At the 20 -cm depth, injecting and evacuating air between 1000 and $1800 \mathrm{HR}$ reduced soil $\mathrm{CO}_{2} \approx 71 \%$ and $76 \%$, from 0.0068 to 0.0020 and $0.0016 \mathrm{~mol} \cdot \mathrm{mol}^{-1}$, respectively.

Continuous 24-h subsurface air movement had no impact on soil $\mathrm{O}_{2}$ levels in any treatment (Table 3). Evacuating and injecting air continuously, at $9 \mathrm{~cm}$, decreased $\mathrm{CO}_{2} \approx 84 \%$ and $80 \%$, from 0.0025 to near atmospheric levels of 0.0004 and $0.0005 \mathrm{~mol} \cdot \mathrm{mol}^{-1}$, respectively. At the 20-cm depth, air movement had no effect on soil $\mathrm{CO}_{2}$. The lack of $\mathrm{O}_{2}$ differences may be attributed to the near atmospheric soil $\mathrm{O}_{2}$ in untreated cells. Reductions in soil $\mathrm{CO}_{2}$ were probably due to rapid replacement of the soil atmosphere by ambient surface air. Decrease in soil $\mathrm{CO}_{2}$ was not dependent upon direction of air movement.

Agreenhouse study performed on creeping bentgrass found that soil $\mathrm{CO}_{2}$ concentrations greater than 0.025 and $0.05 \mathrm{~mol} \cdot \mathrm{mol}^{-1}$ reduced rooting and turf quality (Bunnell et. al, 2002). In this study, soil $\mathrm{CO}_{2}$ concentration in no-air plots reached a maximum level of only 0.0067 $\mathrm{mol} \cdot \mathrm{mol}^{-1}$. The low $\mathrm{CO}_{2}$ concentration in no-air plots might explain the lack of growth response differences from subsurface air treated plots. If this study was performed on a golf green with higher soil $\mathrm{CO}_{2}$ concentrations, rooting and/or turf quality differences might be evident in plots receiving subsurface air movement.

Soil matric potential. Air forced treatments from 0400 to $0600 \mathrm{HR}$ lowered soil matric potential at $9 \mathrm{~cm} \approx 25 \%$ and $11 \%$, from -4.82 in no-air plots to -6.02 and $-5.35 \mathrm{kPa}$, in evacuating and injecting air plots, respectively (Table 3). At $20 \mathrm{~cm}$, evacuating and injecting

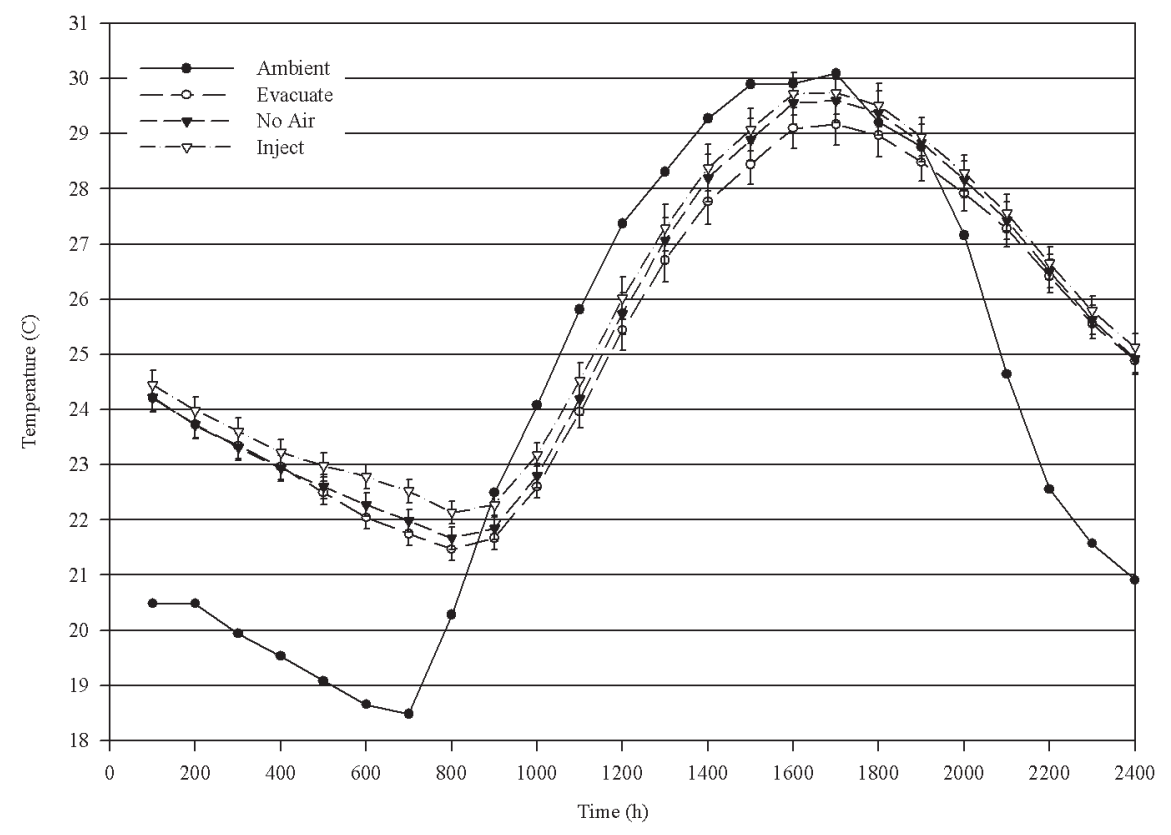

Fig. 1. Average soil and ambient air temperatures over 13-d treatment run 1 (1-13 June) as affected by subsurface air movement (no air, evacuate air, and inject air) from 0400 to $0600 \mathrm{HR}$. Soil temperatures were measured at $9 \mathrm{~cm}$. Vertical bars are \pm SE of $13-\mathrm{d}$ hourly temperature readings.

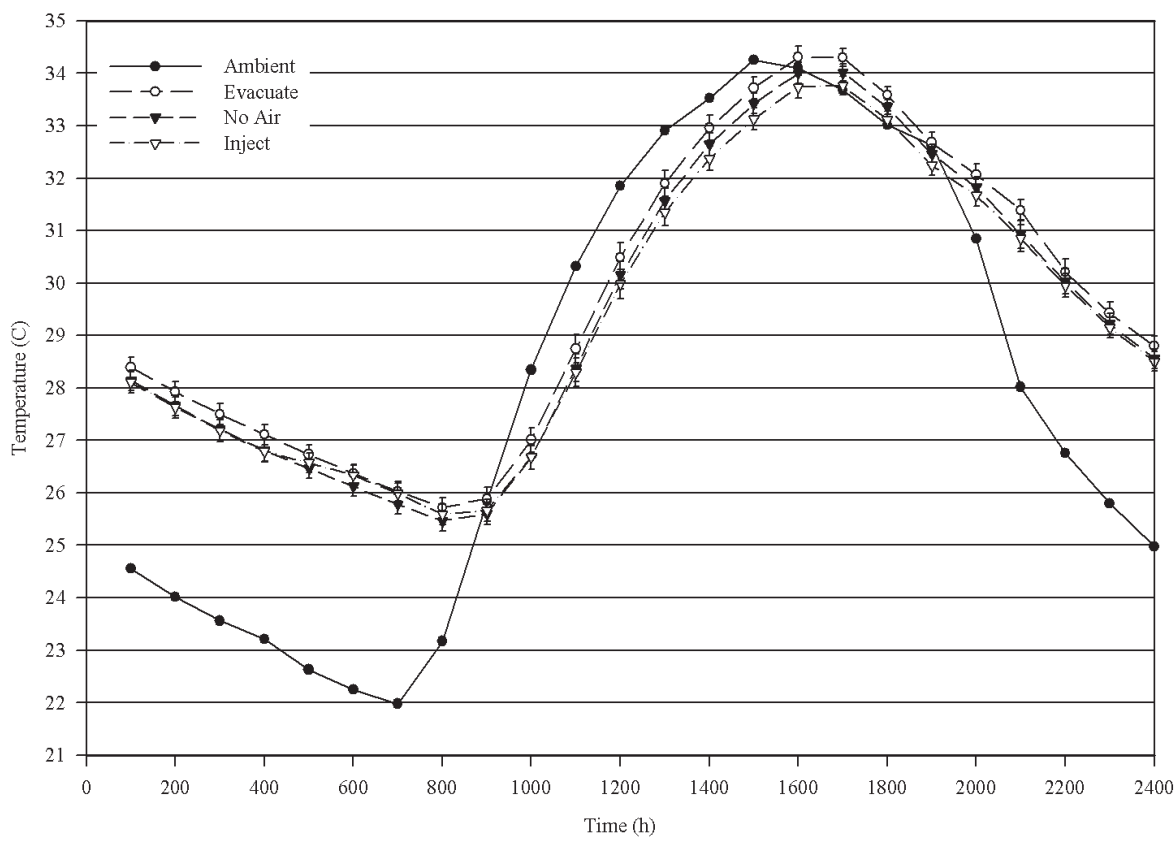

Fig. 2. Average soil and ambient air temperatures over 13-d treatment run 2 (24 July-6 Aug.) as affected by subsurface air movement (no air, evacuate air, and inject air) from 0400 to $0600 \mathrm{HR}$. Soil temperatures were measured at $9 \mathrm{~cm}$. Vertical bars are \pm SE of 13 -d hourly temperature readings.

air lowered soil matric potential $\approx 37 \%$ and $26 \%$, from -2.98 in no-air plots to -4.07 and $-3.75 \mathrm{kPa}$, respectively. Additionally, evacuating air maintained a significantly lower soil matric potential compared to air injection at both depths.

Evacuating and injecting air from 1000 to 1800 HR lowered soil matric potential at the 9 -cm depth $\approx 42 \%$ and $15 \%$, from -3.84 in noair plots to -5.44 and $-4.40 \mathrm{kPa}$, respectively (Table 3). At $20 \mathrm{~cm}$, evacuating and injecting air reduced matric potential $\approx 53 \%$ and $29 \%$, from -2.57 in no-air plots to -3.92 and -3.32 $\mathrm{kPa}$, respectively.
Evacuating and injecting air for $24 \mathrm{~h}$ lowered soil matric potential at $9 \mathrm{~cm} \approx 67 \%$ and $24 \%$, from $-2.91 \mathrm{kPa}$ in no-air plots to -4.86 and $-3.61 \mathrm{kPa}$, respectively (Table 3). Similar trends followed at $20 \mathrm{~cm}$ with evacuating and injecting air lowering soil matric potential $\approx 96 \%$ and $40 \%$, from $-2.00 \mathrm{kPa}$ in no-air plots to -3.93 and $-2.80 \mathrm{kPa}$, respectively.

Subsurface air movement reduced soil matric potential by possibly creating a larger soil water potential gradient throughout the profile. Air evacuation had the greatest impact, reducing matric potential at all duration times. Air injection also reduced matric potential 
from the untreated, but only $\approx 50 \%$ of that with air evacuation.

Plant responses. No differences in turf quality and rooting were observed between treatment combinations. In previous studies, turf quality and rooting improved only after subsurface air movement continued throughout spring and summer months (Camberato, 2000; Walker, 2000). In this study, treatments were imposed for only $13 \mathrm{~d}$. If treatments were imposed for a longer period of time, improvements in turf quality and rooting may have occurred.

Soil temperature. Subsurface air movement direction and duration also influenced soil temperature. Dependent upon time of day and direction of air-flow, a cooling or warming effect was observed. Largest soil temperature differences were observed at mid-afternoon hours between 1400 and 1800 HR. Air evacuation from 0400 to $0600 \mathrm{HR}$ reduced soil temperatures during the early summer first run by less than $0.5^{\circ} \mathrm{C}$ at $9 \mathrm{~cm}$ at mid-afternoon (Fig. 1). Air injection from 0400 to $0600 \mathrm{HR}$ caused only minimal soil temperature differences compared to plots receiving no air.

During the later summer second run, air evacuation from 0400 to $0600 \mathrm{HR}$ increased soil temperatures by $\approx 0.25^{\circ} \mathrm{C}$ at $9 \mathrm{~cm}$ during mid-afternoon (Fig. 2). Air injection, however, decreased soil temperatures by $\approx 0.25^{\circ} \mathrm{C}$ at the 9 -cm depth. Differing ambient air temperatures between experimental runs can be attributed to variations in air temperatures (Figs. 1 and 2 ). During runs 1 and 2 , average minimum temperatures were 18 and $22^{\circ} \mathrm{C}$, respectively and maximum temperatures were 31 and 34 ${ }^{\circ} \mathrm{C}$, respectively. Therefore, the increased minimum ambient air temperatures encountered during run 2 caused air evacuation from 0400 to $0600 \mathrm{HR}$ to increase soil temperatures.

Air injection from 1000 to $1800 \mathrm{HR}$ decreased soil temperature by 1 and $1.2^{\circ} \mathrm{C}$ during runs 1 and 2, respectively, compared to no-air plots at $9 \mathrm{~cm}$ at mid-afternoon (Figs. 3 and 4). In contrast, evacuating air from 1000 to 1800 HR increased soil temperatures compared to no-air plots by $\approx 0.75$ and $0.3{ }^{\circ} \mathrm{C}$ in runs 1 and 2 , respectively, at mid-afternoon.

The differential soil temperature response from evacuation vs. injecting air was probably due to influence of air traveling an underground path through the piping and gravel layer of the golf green where temperatures may be cooler, causing a decrease in soil temperature. In contrast, pulling warmer ambient air directly into the root zone between 1000 and $1800 \mathrm{HR}$ increased soil temperatures with air evacuation treatments. Additional soil temperature response is related to ambient air temperatures when evacuating or injecting air. Maximum and minimum ambient temperatures, with 1000 to 1800 HR duration treatments, were 27 and 20.5 ${ }^{\circ} \mathrm{C}$ during run 1 (Fig. 3) and 33.5 and $21^{\circ} \mathrm{C}$ during run 2 (Fig. 4). The increased maximum temperatures encountered during the second run created a $1.2{ }^{\circ} \mathrm{C}$ temperature decrease in plots receiving air injection compared to no-air plots (Fig. 4). In both runs, evacuating air from 1000 to 1800 HR increased soil temperatures.

Air injection reduced soil temperatures

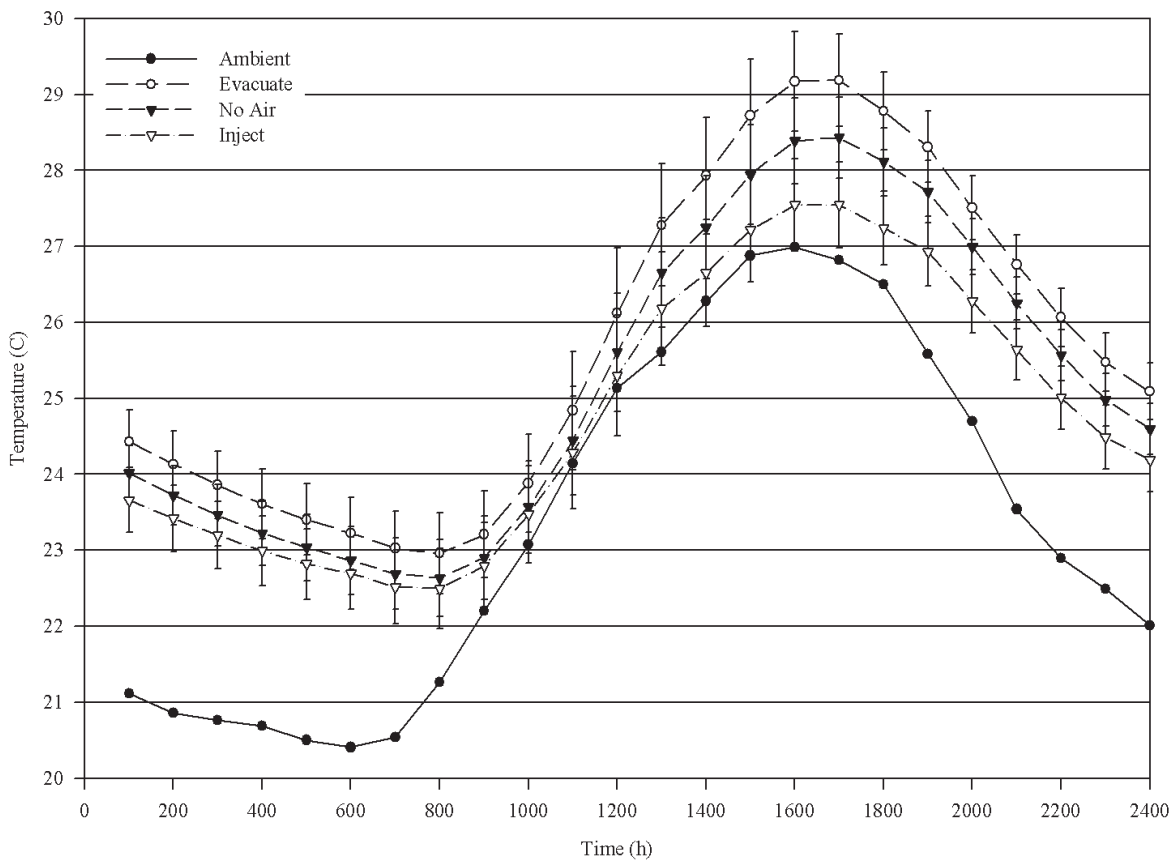

Fig. 3. Average soil and ambient air temperatures over $13 \mathrm{~d}$ treatment run 1 (19 June-1 July) as affected by subsurface air movement (no air, evacuate air, and inject air) from 1000 to $1800 \mathrm{HR}$. Soil temperatures were measured at $9 \mathrm{~cm}$. Vertical bars are $\pm \mathrm{SE}$ of 13 -d hourly temperature readings.

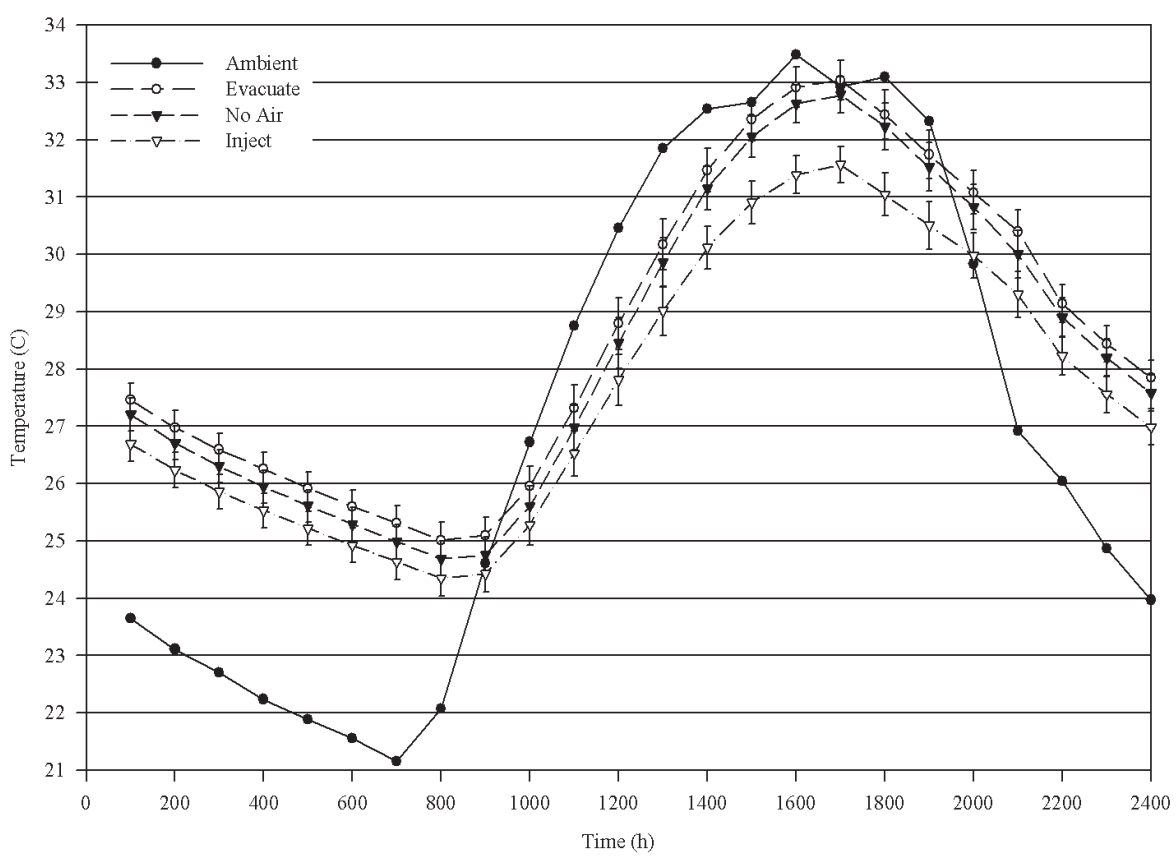

Fig. 4. Average soil and ambient air temperatures over 13-d treatment run 2 (11-23 Aug.) as affected by subsurface air movement (no air, evacuate air, and inject air) from 1000 to $1800 \mathrm{HR}$. Soil temperatures were measured at $9 \mathrm{~cm}$. Vertical bars are $\pm \mathrm{SE}$ of 13 -d hourly temperature readings.

compared to no-air plots during continuous $(24 \mathrm{~h})$ subsurface air movement. In run 1, at the 9-cm depth, air injection reduced soil temperature by $\approx 0.75^{\circ} \mathrm{C}$ at mid-afternoon hours, compared to plots receiving no air. In contrast, air evacuation increased soil temperatures at mid-afternoon by $\approx 0.25{ }^{\circ} \mathrm{C}$ (Fig. 5). The second run followed a similar trend with air injection decreasing soil temperature by $\approx 1.5$ ${ }^{\circ} \mathrm{C}$ at mid-afternoon. In contrast to run 1 , air evacuation decreased soil temperature by $\approx 0.5$ ${ }^{\circ} \mathrm{C}$ compared to no-air plots (Fig. 6). Differ- ences between runs are attributed to changes in ambient air temperatures. Run 1 had an average maximum temperature of $27.5^{\circ} \mathrm{C}$, whereas run 2 had a maximum of $31^{\circ} \mathrm{C}$. The higher ambient air temperatures would increase soil temperatures in plots receiving no air, therefore creating a larger interval between air direction treatments. Greater soil temperature reductions followed evacuating air for $24 \mathrm{~h}$ in run 2 due to lower minimum air temperatures. Minimum temperatures averaged $1{ }^{\circ} \mathrm{C}$ for run 2 compared to $20^{\circ} \mathrm{C}$ for run 1 . The lower night 


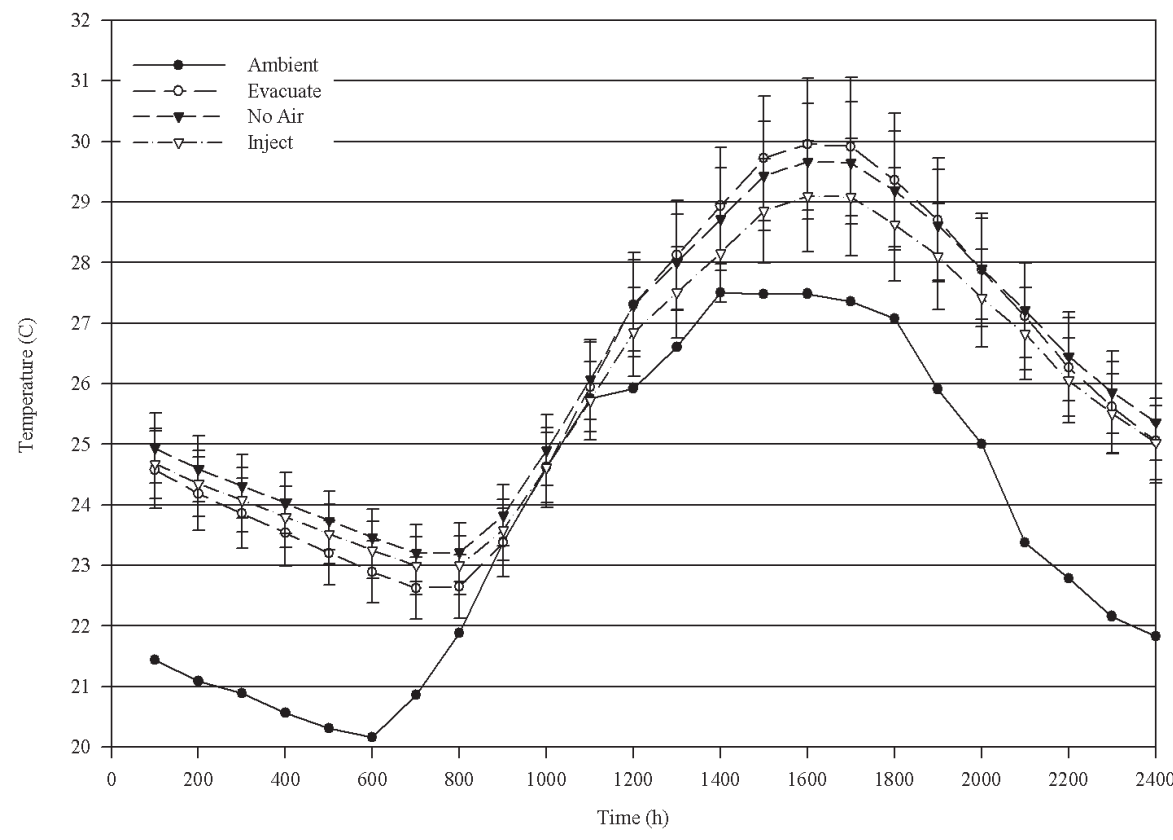

Fig. 5. Average soil and ambient air temperatures over 13-d treatment run 1 (7-19 July) as affected by subsurface air movement (no air, evacuate air, and inject air) for $24 \mathrm{~h}$. Soil temperatures were measured at $9 \mathrm{~cm}$. Vertical bars are \pm SE of 13 -d hourly temperature readings.

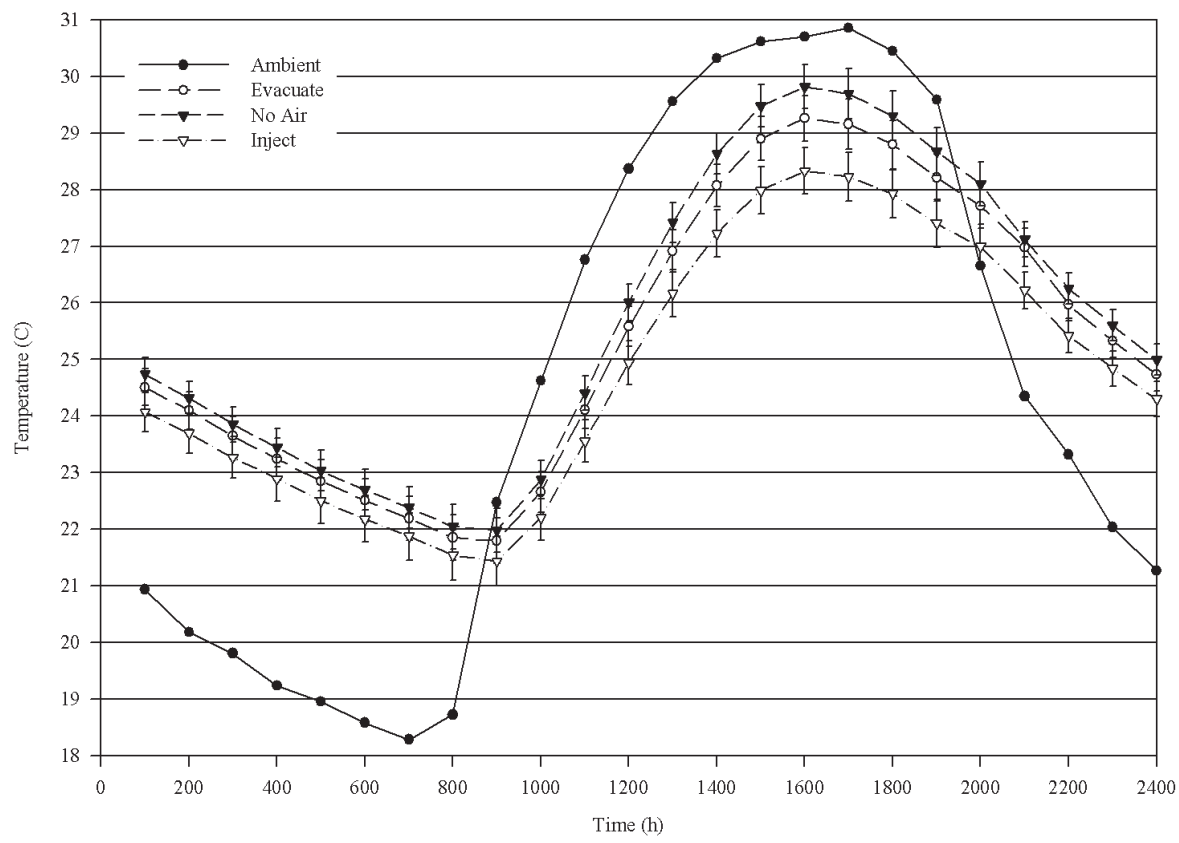

Fig. 6. Average soil and ambient air temperatures over 13-d treatment run (29 Aug.-10 Sept.) as affected by subsurface air movement (no air, evacuate air, and inject air) for $24 \mathrm{~h}$. Soil temperatures were measured at $9 \mathrm{~cm}$. Vertical bars are \pm SE of $13-\mathrm{d}$ hourly temperature readings.

and early morning temperatures during run 2 allowed for air evacuation to have a greater cooling effect.

Air injection treatments during afternoon hours had greatest soil temperature reductions. Air injection from 1000 to $1800 \mathrm{HR}$ and $24 \mathrm{~h}$ reduced soil temperature by greater than $1^{\circ} \mathrm{C}$, whereas air injection from 0400 to $0600 \mathrm{HR}$ had little impact on soil temperature. Therefore, if air injection is used it should be conducted during afternoon hours for maximum soil temperature reductions.

This poses the question if a slight reduction improvements in creeping bentgrass turf quality and root growth may not be expected and did not occur using subsurface air movement, regardless of direction and duration.

Mechanically induced subsurface air movement did not improve turf quality and rooting; however, it proved useful in refining the composition of the soil atmosphere and lowering soil matric potential. This technology potentially holds merit on creeping bentgrass golf greens with poor drainage and a nonconducive growth environment to increase excess water drainage and purging of $\mathrm{CO}_{2}$. Future research should focus on methods of improving soil temperature cooling using air injection during times of heat stress on mature creeping bentgrass golf greens.

\section{Literature Cited}

Bigelow, C.A., D.C. Bowman, D.K. Cassel, and T.W. Rufty, Jr. 2001. Creeping bentgrass response to inorganic soil amendments and mechanically induced subsurface drainage and aeration. Crop Sci. 41:797-805.

Bunnell, B.T., L.B. McCarty, R.B. Dodd, H.S. Hill, and J. Camberato. 2002. Creeping bentgrass growth response to elevated soil carbon dioxide. HortScience 37:367-370.

Beard, J.B. 1973. Turfgrass: Science and culture. Prentice-Hall, Englewood Cliffs, N.J.

Camberato, J. J., R. B. Dodd, S. B. Martin, and S. W. Godwin. 2000. Subsurface cooling and aeration improves bentgrass rooting and turf quality. Golf Course Mgt. 68(9):60-63.

Dodd, R.B., S.B. Martin, and J.J. Camberato. 1999. Subsurface cooling and aeration. Golf Course Mgt. 67(9):71-74.

Huang, B., X. Liu, and J.D. Fry 1998. Shoot physiological responses of two bentgrass cultivars to high temperature and poor soil aeration. Crop Sci. 38:1219-1224.

McCarty, L.B. 2001. Best golf course management practices. Prentice Hall, Upper Saddle River, N.J.

SAS Institute Inc. 1987. SAS/STAT guide for personal computers. Vers. 6 ed. SAS Inst., Cary, N.C.

Smucker, A.J.M., S.L. McBurney, and A.K. Srivastava. 1982. Quantitative separation of roots from compacted soil profiles by the hydropneumatic elutriation system. Agron. J. 74:500-503.

U.S. Golf Association Green Section Staff. 1960. Specifications for a methods of putting green construction. USGA J. Turf Mgt. 13(5):24-28.

U.S. Golf Association Green Section Staff. 1993. USGA recommendations for a method of putting green construction. 1993 Rev. USGA Green Section Record 31(2):1-3.

Waddington, D.V. and J.H. Baker. 1964. Influence of soil aeration on the growth and chemical composition of three grass species. Agron. J. 57:253-258

Walker, R.H., Z. Li, and G. Wehtje. 2000. Roots improve with summertime air movement beneath greens. Golf Course Mgt. 68(8):72-76.

Wiecko, G., R.N. Carrow, and K.J. Karnok. 1993. Turfgrass cultivation methods: Influence on soil physical, root/shoot, and water relationships, p. 451-457. In: R.N. Carrow, N.E. Christians, and R.C. Shearman (eds.). Intl. Turfgrass Soc. Res. J. 7. Overland Park, Kans.

Williamson, R.E. 1964. The effect of root aeration on plant growth. Soil Sci. Soc. Amer. Proc. 28:86-90.

Xu, Q. and B. Huang. 2001. Lowering soil temperatures improve creeping bentgrass growth under heat stress. Crop Sci. 41:1878-1883. 